\title{
Combined test of anterior pituitary function in children
}

\author{
D. C. L. SAVAGE, P. G. F. SWIFT, P. G. B. JOHNSTON, D. J. GOLDIE, AND D. MURPHY \\ From the Royal Hospital for Sick Children, Southmead Hospital, and Bristol Royal Infirmary, Bristol
}

SUMMARY A combined test of anterior pituitary function was used on 21 normal children. It shows that a comprehensive evaluation can be made of growth hormone, thyroid stimulating hormone, adrenocorticotrophic hormone, and gonadotrophin reserve. Simultaneous assessment of those peripheral glands associated with the anterior pituitary is possible by the measurement of thyroid hormones, cortisol, and gonadal steroids. The procedure can be completed in 4 hours with minimum inconvenience and distress to the child.

The development of sensitive radioimmunoassay methods for the measurement of hormones, and the diagnostic use of hypothalamic hormones have greatly simplified the investigation of endocrine disorders. Recently it has become apparent that in the investigation of anterior pituitary function (Mortimer et al., 1973) many tests can be run in parallel. This report confirms the practicability of these methods in a group of 21 normal children.

\section{Material and methods}

Twenty-one boys were referred to the endocrine clinic because of short stature or delayed puberty. No other abnormality had been found. After an overnight fast, an intravenous normal saline infusion was given in a forearm vein. After basal blood samples had been taken, insulin $0.1 \mathrm{U} / \mathrm{kg}$, luteinising hormone-releasing hormone (LH-RH) $100 \mu \mathrm{g}$, and thyrotrophin-releasing hormone (TRH) $200 \mu \mathrm{g}$ were injected intravenously; each injection was given as a single bolus using separate syringes.

Received 1 September 1977
At 120 minutes L-dopa was given orally with the following dosage: weight $<14 \mathrm{~kg}, 125 \mathrm{mg}$; weight $14-32 \mathrm{~kg}, 250 \mathrm{mg}$; weight $>32 \mathrm{~kg}, 500 \mathrm{mg}$ (Table). Serum or plasma was separated and stored at $-20^{\circ} \mathrm{C}$ until assayed.

Serum growth hormone (GH) was measured by double-antibody immunoassay by the method of Hartog et al. (1964), expressed in $\mathrm{mU} / 1$ of the WHO-IRP standard 66/217. Serum thyroid-stimulating hormone (TSH) was measured by doubleantibody radioimmunoassay using reagents supplied by the National Pituitary Agency, USA, and the results were expressed in $\mathrm{mU} / 1$ of MRC standard $68 / 38$. Serum luteinising hormone $(\mathrm{LH})$ and folliclestimulating hormone (FSH) were measured by double-antibody radioimmunoassay and expressed in U/1 of LH standard MRC 68/40 and FSH standard MRC 69/104. Serum testosterone was measured by radioimmunoassay with an antibody raised against testosterone-11 $\alpha-B S A$. Serum thyroxine and triiodothyronine were measured by the radioimmunoassay methods of Challand et al. (1975). Plasma fluorogenic corticosteroids were measured by the method of Mattingly (1962) and

Table Plasma levels of $\mathrm{GH}$, cortisol, glucose, and thyroid-stimulating hormone (TSH) (mean and range)

\begin{tabular}{|c|c|c|c|c|c|c|c|c|c|c|c|}
\hline & $\begin{array}{c}\text { IV insulin, } \\
\downarrow\end{array}$ & $V L H R H, I V$ & $r R H$ & & & $\begin{array}{c}\text { Oral L-dop } \\
\downarrow\end{array}$ & & & & & \\
\hline Time (min) & 0 & 15 & 30 & 60 & 90 & 120 & 160 & 180 & 200 & 220 & 240 \\
\hline $\begin{array}{l}\mathrm{GH}(\mathrm{mU} / \mathrm{l}) \\
\text { Cortisol }(\mathrm{nmol} / \mathrm{l})\end{array}$ & $\begin{array}{l}2 \cdot 4 \\
(2-27 \cdot 9) \\
558 \\
(235-1230)\end{array}$ & & $\begin{array}{l}11 \cdot 3 \\
(2-50)\end{array}$ & $\begin{array}{l}14 \cdot 5 \\
(2-40) \\
876 \\
(510-1390)\end{array}$ & $\begin{array}{l}13 \cdot 7 \\
(2-33)\end{array}$ & $\begin{array}{l}10 \cdot 9 \\
(2-30)\end{array}$ & $\begin{array}{l}14 \cdot 3 \\
(2-67)\end{array}$ & $\begin{array}{l}14 \cdot 7 \\
(2-56)\end{array}$ & $\begin{array}{l}14 \cdot 3 \\
(2-48)\end{array}$ & $\begin{array}{l}9 \cdot 7 \\
(2-25)\end{array}$ & $\begin{array}{l}7 \cdot 0 \\
(2-25)\end{array}$ \\
\hline
\end{tabular}

Conversion : SI to traditional units-Cortisol : $1 \mathrm{nmol} / 1 \approx 0.036 \mu \mathrm{g} / 100 \mathrm{ml}$. Glucose: $1 \mathrm{mmol} / 1 \approx 18 \mathrm{mg} / 100 \mathrm{ml}$. 
blood glucose by a modification (Pennock et al., 1973) of the glucose oxidase method of Trinder (1969).

\section{Results}

Growth hormone. Intravenous insulin gave satisfactory hypoglycaemia, that is a decrease $>50 \%$ of the fasting blood glucose level, in 17 of the 21 children. No child experienced more than mild drowsiness during this part of the procedure.

In our laboratory a normal GH response consists of a peak level of at least $8 \mathrm{mU} / 1$; this is in general agreement with most other investigators (Root et al., 1967; Frasier, 1967; Kaplan et al., 1968; Joss, 1975). After insulin-induced hypoglycaemia, 2 children had an inadequate $\mathrm{GH}$ response. After L-dopa 5 of the 21 children had a peak GH response $<8 \mathrm{mU} / 1 ; 3$ vomited the drug so that the test had to be terminated, and many of the children were nauseated. With these two sequential tests, in only 1 of 18 children (6\%) did the GH levels not reach $8 \mathrm{mU} / \mathrm{l}$. The mean response and the range are shown in the Table.

TSH and thyroid hormones. The basal levels of TSH were $<3.5 \mathrm{mU} / 1$. After TRH plasma TSH reached a peak at 30 minutes, declining towards basal levels at 120 minutes. There was a large variability in individual responses to TRH. The mean response and the range are shown in the Table.

The mean basal thyroxine level was $117 \mathrm{nmol} / 1$ $(9 \mu \mathrm{g} / 100 \mathrm{ml})$, range $91-136 \mathrm{nmol} / 1(7-10.6 \mu \mathrm{g} / 100$ $\mathrm{ml}$; and the mean basal triiodothyronine level 1.6 $\mathrm{nmol} / 1(1.04 \mu \mathrm{g} / 100 \mathrm{ml})$, range $1.5-1.8 \mathrm{nmol} / 1$ $(0 \cdot 98-1 \cdot 17 \mu \mathrm{g} / 100 \mathrm{ml})$. In all but 3 children both thyroxine and triiodothyronine levels increased at 2 hours after TRH; the mean increase in thyroxine concentration was $20.9 \mathrm{nmol} / 1(1.6 \mu \mathrm{g} / 100 \mathrm{ml})$ (17\% rise), range 0-55 $\mathrm{nmol} / 1(0-4 \cdot 3 \mu \mathrm{g} / 100 \mathrm{ml})$; and triiodothyronine $0.5 \mathrm{nmol} / 1(0.33 \mu \mathrm{g} / 100 \mathrm{ml})$ ( $31 \%$ rise), range $0-1 \cdot 1 \mathrm{nmol} / 1(0-0.72 \mu \mathrm{g} / 100 \mathrm{ml})$.

Gonadotrophins and gonadal steroids. After LH-RH, plasma LH reached a peak at 15-30 minutes (Fig. 1). Prepubertally there was a moderate rise in $\mathrm{LH}$; the smallest increase above basal levels was $2 \cdot 7 \mathrm{U} / 1$ and the greatest peak response $8.0 \mathrm{U} / 1$. At puberty there was a marked increase in the LH surge after LH-RH, the minimum peak response being $10 \cdot 2 \mathrm{U} / 1$.

The release of FSH after LH-RH was maximal at 60 minutes. As a group, the pubertal boys had a greater response to LH-RH than the prepubertal boys, but in an individual test no clear distinction could be made between a prepubertal or pubertal response (Fig. 2).
Prepubertally there was no difference in the basal and 4-hour testosterone levels which were all $<3 \mathrm{nmol} / \mathrm{l}(0 \cdot 87 \mathrm{ng} / \mathrm{ml})$. At puberty testosterone levels 4 hours after LH-RH were 2-12 nmol/1 $(0.58-3.46 \mathrm{ng} / \mathrm{ml})$ higher than basal levels, and the percentage rise was greatest at mid- to late puberty.

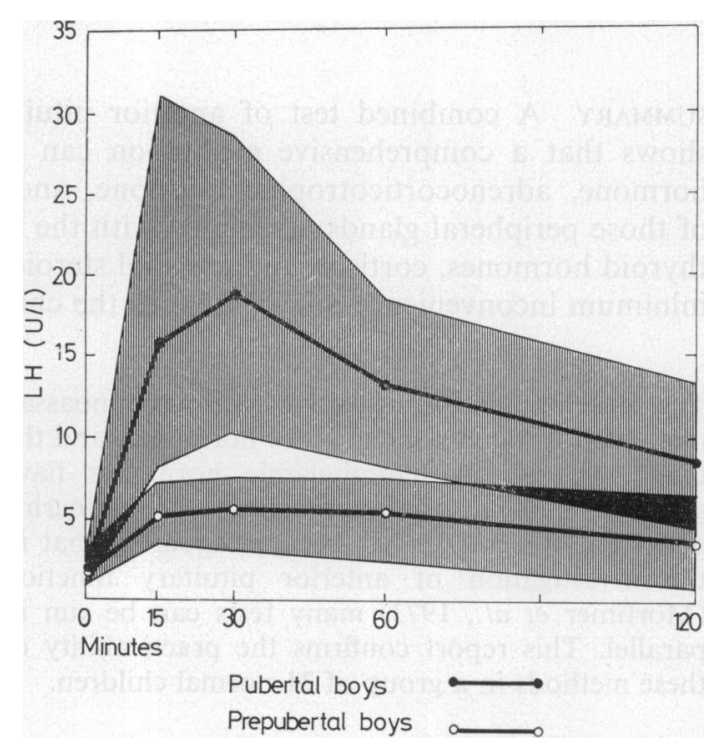

Fig. 1 Effect of $100 \mu \mathrm{g} L H-R H$ on serum LH in prepubertal and pubertal boys: mean and range.

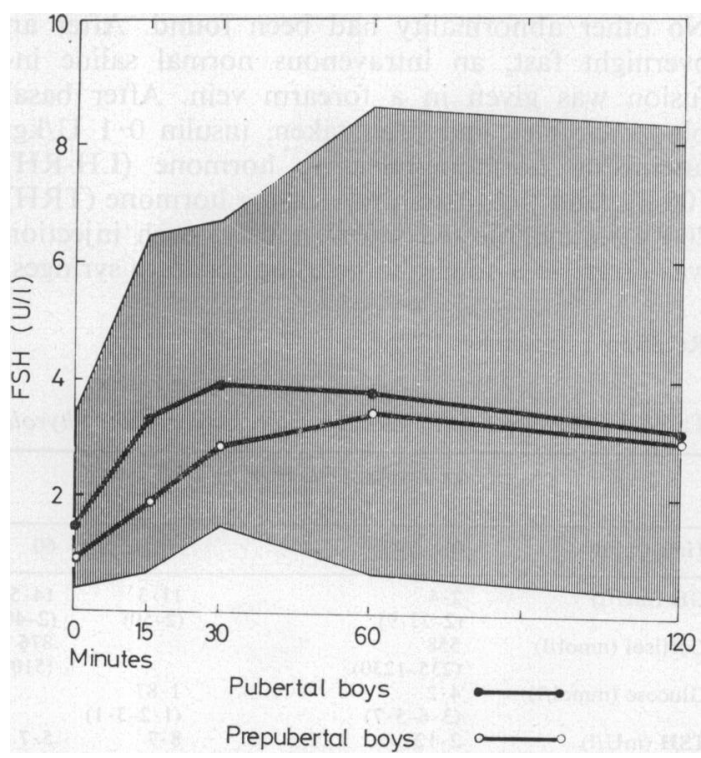

Fig. 2 Effect of $100 \mu \mathrm{g}$ LH-RH on serum FSH in prepubertal and pubertal boys: mean and range. 
We found a similar pattern of response with oestradiol levels in girls.

Cortisol. The mean basal and 60-minute cortisol levels are given in the Table. Those children with basal cortisol levels $>700 \mathrm{nmol} / \mathrm{l}(25 \cdot 4 \mu \mathrm{g} / 100 \mathrm{ml})$ did not show a rise after insulin-induced hypoglycaemia.

\section{Discussion}

In adults the advantage of a combined test to assess the reserve of anterior pituitary hormones has been clearly shown (Mortimer et al., 1973). There is only one similar account in children (Girard et al., 1975). Both reports show that the simultaneous administration of insulin and the hypothalamic releasing hormones, LH-RH and TRH, do not alter the hormonal response from that seen during a specific single test.

Insulin-induced hypoglycaemia is the most reliable definitive test for GH release. However, it is important to use two sequential tests since any single stimulus may fail to induce growth hormone release in $10-15 \%$ of normal children (Kaplan et al., 1968; Frasier, 1974). We used L-dopa as the second stimulus for GH release (Boyd et al., 1970; Weldon et al., 1975), but the timing of the response was unpredictable and nausea and vomiting reduced the acceptability of the drug. For this reason we now use arginine $(0.5 \mathrm{~g} / \mathrm{kg})$ infused over 30 minutes as the second stimulus.

With these sequential tests only one child had GH peaks $<8 \mathrm{mU} / 1$ : a boy of normal stature under investigation for delayed pubertal development, a time at which there is often a poor response to $\mathrm{GH}$ stimulation tests (Penny and Blizzard, 1972). In the investigation of $\mathrm{GH}$ reserve, the initial blood samples for GH should be taken immediately the intravenous infusion is set up, since the stress of the procedure often induces $\mathrm{GH}$ release with a subsequent refractory period during the GH stimulation tests (Joss, 1975).

Recently Maeda et al. (1976) showed that GH release is significantly inhibited after insulin-induced hypoglycaemia when $1000 \mu \mathrm{g}$ TRH is infused before and during the test period. However, Besser has shown that a bolus of $200 \mu \mathrm{g}$ TRH has no significant effect on GH release when insulin and TRH are given simultaneously (Besser et al., 1971). Our results confirm this, since the mean $\mathrm{GH}$ level of $14 \mathrm{mU} / 1$ is similar to that we have found when insulin is used alone and is markedly different from those of GHdeficient subjects whose $\mathrm{GH}$ peaks have ranged from $<2$ to $4 \mathrm{mU} / 1$.
A TRH test is not often necessary since basal plasma thyroxine, triiodothyronine, and TSH levels give good information of thyroid status. However, for suspected hypothalamic or pituitary disease, the test is valuable and its combined administration with other releasing hormones or insulin has proved satisfactory. In adults the release of TSH following TRH is accompanied by a peak increase of serum triiodothyronine at 2-3 hours and serum thyroxine at 6-8 hours (Shenkman et al., 1972; Lawton et al., 1973; Patel and Burger, 1973). Although our study confirms the proportionately greater rise of triiodothyronine compared with thyroxine at 2 hours, 3 children showed no rise above basal levels of either. We now measure both at 2 and 4 hours respectively. These values in conjunction with the TSH response allow a full assessment of both the thyroid reserve and the integrity of the pituitary-thyroid axis.

As reported by others we found that at the onset of puberty there was a marked increase in $\mathrm{LH}$ release after LH-RH. This pattern is similar in both sexes (Job et al., 1972; Roth et al., 1973). FSH release after LH-RH does not distinguish the prepubertal from the pubertal child, and the FSH response in girls is generally greater than in boys at all ages (Job et al., 1972; Suwa et al., 1974; Franchimont et al., 1974).

An increase in plasma cortisol after insulininduced hypoglycaemia is a satisfactory reflection of the ability of the hypothalamic pituitary axis to release ACTH. When necessary, ACTH should be measured not only at $\mathbf{0}$ and $\mathbf{3 0}$ minutes but also at 60,90 , and 120 minutes to detect the maximum levels reached after hypoglycaemia.

We have not measured prolactin regularly since its assay is rarely required in paediatric practice. Its release follows insulin-induced hypoglycaemia (Frantz et al., 1972) and also TRH stimulation (Friesen et al., 1972) so that basal samples and levels at 30 and 60 minutes give information of the hypothalamic-pituitary prolactin status. It has been shown that its measurement can be satisfactorily incorporated in a combined test of anterior pituitary function (Mortimer et al., 1973).

This combined test greatly simplifies the investigation of endocrine disorders in children, allowing a full assessment of the hypothalamicanterior pituitary axis and peripheral gland reserve (thyroid, adrenal, and gonads). It is, however, relatively expensive and time consuming and should not be used as a screening test for growth hormone deficiency but reserved for the child with suspected hypopituitarism. It is now our practice to admit these children overnight and to discharge them after completion of the test within 24 hours. 


\section{References}

Besser, G. M., Ratcliffe, J. G., Kilborn, J. C., Ormston, B. J., and Hall, R. (1971). Interaction between thyrotrophin, corticotrophin and growth hormone secretions in man. Journal of Endocrinology, 51, 699-706.

Boyd, A. E., Lebowitz, H. E., and Pfeiffer, J. B. (1970). Stimulation of human growth hormone secretion by L-dopa. New Eng!and Journal of Medicine, 283, 1425-1429.

Challand, G. S., Ratcliffe, W. A., and Ratcliffe, J. G. (1975). Semi-automated radioimmunoassays for total serum thyroxine and triiodothyronine. Clinica Chimica Acta, 60, 25-32.

Franchimont, P., Becker, H., Ernould, Ch., Thys, Ch., Delmoulin, A., Bourgiugnon, J. P., Legros, J. J., and Valcke, J. C. (1974). The effect of hypothalamic luteinizing hormone (LH-RH) on plasma gonadotrophin levels in normal subjects. Clinical Endocrinology, 3, 27-39.

Frantz, A. G., Kleinberg, D. L., and Noel, G. L. (1972). Studies on prolactin in man. Recent Progress in Hormone Research, 28, 527-590.

Frasier, S. D. (1967). The serum growth hormone response to hypoglycemia in dwarfism. Journal of Pediatrics, 71, 625-638.

Frasier, S. D. (1974). A review of growth hormone stimulation tests in children. Pediatrics, 53, 929-936.

Friesen, H., Guyda, H., Hwang, P., Tyson, J. E., and Barbeau, A. (1972). Functional evaluation of prolactin secretion: a guide to therapy. Journal of Clinical Investigation, 51, 706-709.

Girard, J., Staub, J. J., Baumann, J. B., and Nars, P. W. (1975). Assessment of hypothalamo-pituitary secreting capacity in children on the basis of a single test. (Abst.) Pediatric Research, 9, 686.

Hartog, M., Gaafar, M. A., Meisser, B., and Fraser, T. R. (1964). Immunoassay of serum growth hormone in acromegalic patients. British Medical Journal, 2, 1229-1232.

Job, J. C., Garnier, P. E., Chaussain, J. L., and Milhaud, G. (1972). Elevation of serum gonadotrophins (LH and FSH) after releasing hormone (LH-RH) injection in normal children and in patients with disorders of puberty. Journal of Clinical Endocrinology and Metabolism, 35, 473-476.

Joss, E. E. (1975). Growth Hormone Deficiency in Childhood. Evaluation of Diagnostic Procedures. Karger, Basel.

Kaplan, S. L., Abrams, C. A. L., Bell, J. J., Conte, F. A., and Grumbach, M. M. (1968). Growth and growth hormone. I. Changes in serum level of growth hormone following hypoglycemia in 134 children with growth retardation. Pediatric Research, 2, 43-63.

Lawton, N. F., Ellis, S. M., and Sufi, S. (1973). The triiodothyronine and thyroxine response to thyrotrophinreleasing hormone in the assessment of the pituitarythyroid axis. Clinical Endocrinology 2, 57-63.

Maeda, K., Kato, Y., Chihara, K., Ohgo, S., Iwasaki, Y., Abe, H., and Imuna, H. (1975). Suppression by thyrotrophin releasing hormone (TR:) of growth hormone release induced by arginine and insulin induced hypoglycemia in man. Journal of Clinical Endocrinology and Metabolism, 43, 453-456.

Mattingly, D. (1962). A simple fluorometric method for the estimation of free 11-hydroxycorticoids in human plasma. Journal of Clinical Pathology, 15, 374-379.

Mortimer, C. H., Besser, G. M., McNeilly, A. S., Tunbridge, W. M. G., Gomez-Pan, A., and Hall, R. (1973). Interaction between secretion of the gonadotrophins, prolactin, growth hormone, thyrotrophin and corticosteroids in man: the effects of LH/FSH-RH, TRH and hypoglycaemia alone and in combination. Clinical Endocrinology, 2, 317-326.

Patel, Y. C., and Burger, H. G. (1973). Serum triiodothyronine in health and disease. Clinical Endocrinology, 2, 239-349.

Pennock, C. A., Murphy, D., Sellers, J., and Longdon, K. J. (1973). A comparison of autoanalyser methods for the estimation of glucose in blood. Clinica Chimica Acta, 48, 193-201.

Penny, R., and Blizzard, R. M. (1972). The possible influence of the release of growth hormone in three males with apparent isolated growth hormone deficiencies. Journal of Clinical Endocrinology and Metabolism, 34, 82-84.

Root, A. W., Rosenfield, R. L., Bongiovanni, A. M., and Eberlein, W. R. (1967). The plasma growth hormone response to insulin induced hypoglycemia in children with retardation of growth. Pediatrics, 39, 844-852.

Roth, J. C., Grumbach, M. M., and Kaplan, S. L. (1973). Effect of synthetic luteinizing hormone-releasing factor on serum testosterone and gonadotrophins in prepubertal, pubertal and adult males. Journa lof Clinical Endocrinology and Metabolism, 37, 680-686.

Shenkman, L., Mitsuma, T., Suphavai, A., and Hollander, C. S. (1972). Triiodothyronine and thyroid stimulating hormone response to thyrotrophin-releasing hormone. A new test of thyroidal and pituitary reserve. Lancet, 1, 111-113.

Suwa, S., Maesaka, H., and Matsui, I. (1974). Serum LH and FSH responses to synthetic LH-RH in normal infants, children and patients with Turner's syndrome. Pediatrics, 54, 470-475.

Trinder, P. (1969). Determination of glucose in blood using glucose oxidase with an alternative oxygen acceptor. Annals of Clinical Biochemistry, 6, 24-27.

Weldon, V. V., Gupta, S. K., Klingensmith, G., Clarke, W. L., Duck, S. C., Haymond, W., and Pagliara, A. S. (1975). Evaluation of growth hormone release in children using arginine and L-dopa in combination. Journal of Pediatrics, 87, 540-544.

Correspondence to Dr D. C. L. Savage, Royal Hospital for Sick Children, St Micinael's Hill, Bristol BS2 8BJ. 